\title{
A problemática espacial e a história ambiental ${ }^{1}$ The spatial issues and environmental history
}

\author{
Haruf Salmen Espindola*
}

\begin{abstract}
Resumo
A proposta de discutir a problemática espacial para a história ambiental nos remete à questão do espaço e de como o imaginamos, bem como à relação entre história-geografia. A história ambiental, mas que outros ramos da ciência histórica, deve se voltar para o espaço, para se perguntar como a escala afeta os fenômenos socioambientais. Esse artigo está dividido em três partes: primeiro se discute os conceitos de poder e território, para em seguida examinar a problemática da escala, do tempo e dos agenciamentos, finalizando com a reflexão sobre as implicações da escala para a investigação em história ambiental.

Palavras-chaves: História Ambiental; Espaço; Território; Poder e Escala.
\end{abstract}

\begin{abstract}
This work aims to discuss the problem of space of environmental history, which, in turn, demands to think space and how we imagine it, as well as the relationship between history and geography. Environmental history, more than other fields of the historical science, must think about space, in order to ask how the scale affects social environmental phenomena. This article is divided in three parts: first the concepts of power and territory are discussed, and next the problem of scale of time and agencies is tackled, in order to finish with the reflection about the implication of the scale for the research in environmental history.
\end{abstract}

Key words: Environmental history; Space; Territory; Power and scales

\footnotetext{
* Doutor em História Econômica pela USP, Professor titular da Universidade Vale do Rio Doce, vinculado ao Programa de Pós-graduação Interdisciplinar em Gestão Integrada do Território. E-mail: harufse@ gmail.com

${ }^{1}$ Este artigo foi produzido como uma das atividades do projeto "As delimitações espaciais sobre a pesquisa em história ambiental", financiado pelo CNPq - Chamada Universal 14/2012.
} 
A proposta de uma abordagem espacial para a história ambiental nos remete à questão do espaço e de como o imaginamos, bem como à relação entre história-geografia. Boaventura Santos ${ }^{2}$ afirma ter as ciências sociais se constituído na égide da metáfora temporal (e da ideia de progresso). "De facto, assim parecer ser. A metáfora fundadora do pensamento moderno é a ideia do progresso e dela decorrem aquelas em que assentam as ciências sociais, nomeadamente a metáfora do desenvolvimento". Essa vitória do tempo teria levado a própria geografia "a reduzir o espaço às relações sociais ocorrendo no espaço e, por isso, quase perdera o seu próprio espaço científico no seio das restantes ciências sociais." Na década de 1980, segundo o autor, se assistiu a um "renascimento do espaço", inclusive nas ciências sociais, porém ele alertava que em lugar de se estudar as relações sociais ocorrendo no espaço, "trata-se agora de investigar o que, nas relações sociais, resulta especificamente do facto de estas ocorrerem no espaço”. No Brasil, as décadas de 1980/1990 foram marcadas por intensas e extensas discussões entre os geógrafos sobre o espaço, nas quais se destacou Milton Santos. ${ }^{3}$

A tendência da história, ao lidar com o espaço, tem sido reduzi-lo à superfície onde os eventos ocorrem. Tradicionalmente não se preocupou em refletir sobre o espaço, visto ser o tempo e a narrativa sua ferramenta. A historiografia do século XX tem muitos exemplos de obras que traziam um primeiro capítulo sobre a geografia, porém o restante "contava" a história que realmente interessava. Evidente que temos autores que foram excepcionalmente cuidadosos com a questão espacial, tais como Sérgio Buarque de Holanda (Moções; Caminhos e Fronteiras; Visão do Paraiso), Lucien Febvre (O Reno: histórias, mitos e realidades.); Fernand Braudel (O Mediterrâneo e o Mundo Mediterrânico; O Espaço e a História no Mediterrâneo), mas especialmente a história ambiental produzida nos Estados Unidos da América

\footnotetext{
${ }^{2}$ Santos, Boaventura de Sousa. Uma cartografia simbólica das representações sociais: prolegômenos a uma concepção pós-moderna do Direito. Revista Crítica de Ciências Sociais, Coimbra, n. 24, p. 139-172, 1988, p. 139-140. Disponível em http://www.boaventuradesousasantos.pt/media/pdfs/Cartografia_simboliCa_RCCS24.PDF. Acessado em 21 de junho de 2014.

${ }^{3}$ A obra de Milton Santos foi um marco nos debates e estudos da geografia brasileira, nos últimos quatro décadas. SANTOS, Milton. Economia espacial: críticas e alternativas. SP: Hucitec, 1979; Espaço e sociedade. Petrópolis: Vozes, 1979; O espaço dividido. Os dois circuitos da economia urbana dos países subdesenvolvidos. Rio de Janeiro: Francisco Alves, 1979; Pensando o espaço do homem. São Paulo: Hucitec, 1982; Espaço e Método. São Paulo: Nobel, 1985; A construção do espaço. São Paulo: Nobel, 1986; O espaço do cidadão. São Paulo: Nobel, 1987; Metamorfoses do espaço habitado. Paulo: Hucitec, 1988; Metrópole corporativa fragmentada: o caso de São Paulo. São Paulo: Nobel/Secretaria de Estado da Cultura, 1990; A urbanização brasileira. São Paulo: Hucitec, 1993; Técnica, espaço, tempo. São Paulo: Editora Hucitec, 1994; A Natureza do Espaço. São Paulo, EDUSP, 1996. Por uma outra globalização - do pensamento único à consciência universal. São Paulo: Editora Record, 2000.
} 
(EUA). Entretanto, como destaca o historiador ambiental americano, Willian Cronon, a narrativa tem sido a ferramenta fundamental manejada pelo historiador: "O sucesso da narrativa é proporcional à extensão com que escondem as descontinuidades, elipses e contradições que solapariam o sentido pretendido para a história." ${ }^{4}$

Isso significa que o sucesso se baseia na eliminação das pluralidades presentes no espaço, especialmente as relacionalidades e emergências espaciais não controladas, pois prejudicariam "o sentido pretendido pela história”. Nesse sentido, destaca-se a importância da história ambiental discutir sobre a problemática espacial. O presente artigo propõe enfrentar essa questão, como parte do projeto "As delimitações espaciais na pesquisa em história ambiental", aprovado no edital Universal do CNPq, em 2012. ${ }^{5}$ Dividimos o artigo em três partes, tratando primeiro dos conceitos de poder e território, para em seguida discutir a problemática da escala, finalizando com a reflexão sobre as implicações da escala para a investigação em história ambiental.

\section{História ambiental, território e poder}

A história ambiental tem muito a contribuir se desprender das categorias criadas pela unidimensionalidade espaço-temporal do Estado e do nacional, que se constituíram de forma dominante no século XIX. A renovação proposta pela escola dos Annales, com sua história socioeconômica, ou a produção crítica do pensamento de esquerda, especialmente pela influência dos historiadores marxistas britânicos, em muitos aspectos reforçaram a escala estatal-nacional, especialmente no contexto da primeira metade do século $\mathrm{XX}$, fortemente marcado pelos diversos nacionalismos. A história ambiental tem utilizado o "nacional" como escala espacial para a análise, inclusive a organização dos historiadores ambientais como sociedades se fundamenta nessa dimensão escalar. Apesar do uso da dimensão nacional, grande parte dos trabalhos em história ambiental tem se concentrado em estudos de áreas bem menores (localidades, micro ou mesorregiões de determinado

\footnotetext{
${ }^{4}$ CRONON, Willian. A Place for Stories: Nature, History, and Narrative. The Journal of American History, 78, 4, 1992, p. 1349-1350, p. 1349.

${ }^{5} \mathrm{O}$ projeto "As delimitações espaciais na pesquisa em História ambiental” é financiado pelo CNPq, Processo: 482250/2012-7. A coordenação é do Prof. Dr. Gilmar Arruda - UEL/PR; os participantes são professores doutores Alessandra Izabel de Carvalho - UEPG/PR; Dora Shellard Correa - UNIFIEO/SP; Ely Bergo Carvalho - UFMG/MG; Eunice Nodari - UFSC/SC; Haruf Salmen Espindola - UNIVALE/MG; Jó Klanovicz - UNICENTRO/PR; José Augusto Drummond - UNB/Brasília; José Augusto Pádua - UFRJ; Rogério Ribeiro Oliveria - PUC-RJ.
} 
estado da federação) ou, no máximo, abrangem um estado federado, sendo raros estudos mais abrangentes.

A produção intelectual brasileira, dominante no século XX, foi fortemente marcada pela matriz reducionista do Estado (pensar o Brasil, conhecer o Brasil, mudar o Brasil etc.). O Estado foi entendido como determinante da produção do ordenamento jurídico, sociopolítico, cultural, econômico e territorial brasileiro. As interpretações sobre o Brasil foram determinadas pela escala estatal-nacional, tanto por parte daqueles comprometidos com o projeto state building, a exemplo de Alberto Torres e Oliveira Vianna; como o pensamento crítico, cujo leque variava do pensamento social católico (Alceu Amoroso Lima e Dom Hélder Câmara) ao pensamento de esquerda (Caio Prado Júnior e Nelson Werneck Sodré). A marca da intelligentsia brasileira (nascida com a República) ${ }^{6}$ foi o compromisso de fazer do conhecimento um instrumento de transformação do Brasil, de construção da unidade nacional, de juntar sertão e litoral num único país, de fazer o país "legal" encontrar o país "real". Além de centrada na escala estatal-nacional, partilhavam uma expectativa de modernização conforme o modelo dos países desenvolvidos europeus ou dos EUA. O Brasil era visto negativamente como uma "colcha de retalhos" que carecia de unidade para sair do "atraso" social e econômico".

O espaço-tempo estatal-nacional constituído no processo de formação histórica do Estado moderno, no século XIX, foi um processo de construção da dimensão imaginária da nacionalidade, conforme Benedict Anderson; ${ }^{8}$ ou, como bem observa Hobsbawm: ${ }^{9}$ nada semelhante existia antes do século XIX. A questão que se coloca aqui é a distorção produzida por interpretações históricas fundamentadas no pressuposto da existência de uma entidade coletiva que não existia, pelo menos antes de meados do século XIX, para

\footnotetext{
${ }^{6}$ A expressão "geração que nasceu com a República" identifica os autores da obra coletiva publicada no Rio de Janeiro, em 1924, organizada por Vicente Licínio Cardoso (À Margem da História da República): Carneiro Leão, Celso Vieira, Gilberto Amado, Oliveira Vianna, Pontes de Miranda, José António Nogueira, Ronald de Carvalho, Alceu Amoroso Lima, entre outros. São intelectuais que, na maioria, teriam papel destacado nas décadas seguintes. Todos tinham em comum a mesma preocupação: o que fazer para salvar o Brasil, para fazê-lo progredir. Preocupação comum aos participantes da Semana de Arte Moderna de 1922. Para essa geração o "ser nacional", a "comunidade nacional" e o brasileiro como "ser histórico" dependiam do aperfeiçoamento da nacionalidade. ESPINDOLA, Haruf Salmen. Centauro Maquiavélico. Brasília: UnB, 1988. p.143-145. (Dissertação de Mestrado)

${ }^{7}$ ESPINDOLA, op. cit. p. 125.

${ }^{8}$ ANDERSON, Benedict. Comunidades imaginadas: reflexões sobre a origem e a difusão do nacionalismo. São Paulo: Companhia das Letras, 2008.

${ }^{9}$ HOBSBAWM, Eric J. Nações e nacionalismo desde 1780. Programa, Mito e Realidade. São Paulo: Paz e Terra, 2008.
} 
a maior parte dos atuais Estados. Adotar uma escala nacional-estatal é subordinar a interpretação histórica à uma imaginação contemporânea. Aqui se está diante da questão da relação entre território e poder, bem como da mediação que a escala desempenha nessa relação.

Segundo Milton Santos, ${ }^{10}$ as escalas expressam diferentes níveis de totalidade: mundial (pequena escala); ou territorial - estatal-nacional (pequena e média escala); e local (grande escala). A escala do nível estatal-nacional (nação, país, território, Estado) apresentaria uma maior unidade de pensamento pela concretude totalizadora - formação socioespacial - produzida pela territorialidade resultante de um contrato e limitada por fronteiras. ${ }^{11}$ Para o autor a mundialização criada pelas redes teria enfraquecido as fronteiras e comprometido o contrato, porém isso teria se dado seletivamente, em função do Mundo ser "apenas um conjunto de possibilidades, cuja efetivação depende das oportunidades oferecidas pelos lugares". Se por um lado o capital subordinou a territorialidade estatal à lógica do mercado, por outro lado, para as demais esferas o Estado manteve, ou até ampliou, o poder de regulação e controle, além de ter permanecido como referência central do pensamento. Isso decorre do fato do Estado (formação socioespacial estatal-nacional) funcionar como "mediação entre o mundo e a região, o lugar".

Para Santos, o lugar é a terceira totalidade, onde se dá a concretude efetiva e única do existir e realizar, seja como espaço banal criado pela contiguidade; as singularidades de cada lugar; e as condensações particulares dos fragmentos das redes, cujos sentidos somente podem ser vistos na pequena escala, particularmente os produzidos pela reticularidade criada pelas novas tecnologias de informação e comunicação. A grande escala possibilita observar os detalhes e diferenças na contiguidade de fenômenos sociais agregados, que são baseados no acontecer solidário, fruto da pluralidade e do acontecer repetitivo, mesmo que não exclua as surpresas e novidades. $\mathrm{Na}$ relação entre os três níveis (mundo, território e lugar), o território, em última instância, opera a mediação.

Mas o território termina por ser a grande mediação entre o mundo e a sociedade nacional e local, já que, em sua funcionalização, o "mundo" necessita da mediação dos lugares, segundo as virtualidades destes para usos específicos. Num dado momento, o "mundo" escolhe alguns lugares e rejeita outros e, nesse movimento, modifica o conjunto dos lugares, o espaço como um todo.

\footnotetext{
${ }^{10}$ SANTOS, 1996, op. cit. p. 270-271.

${ }^{11}$ Para Milton Santos o "que chamamos de sociedade somente adquire concretude quando a enxergamos simultaneamente como continente e como conteúdo dos objetos.” Ibidem, p. 95.
} 
É o lugar que oferece ao movimento do mundo a possibilidade de sua realização mais eficaz. Para se tornar espaço, o mundo depende das virtualidades do lugar. Nesse sentido pode-se dizer que, localmente, o espaço territorial age como norma. ${ }^{12}$

Isso nos remete ao fato de o espaço relacional ser uma problemática diretamente afetada pela categoria de poder, tendo em vista serem as intencionalidades presentes nas relações de poder que se inscrevem nos espaços e os organizam, conforme as diferentes escalas. Assim, deparamos com a história política, que ainda é vista com restrição ou é refutada, como se ainda fosse a velha história positivista. Foi René Rémond que capitaneou a renovação da história política, particularmente depois da publicação da obra Pour une Histoire Politique, em $1988 .{ }^{13}$ A nova abordagem, além da crítica à maneira "equivocada" de se fazer a história política, incorporou a problemática sobre a natureza da política e do poder, bem como sobre as relações do político com os outros níveis da realidade social. Deixou-se de ver a política como um reflexo das estruturas socioeconômicas, restituindo-lhe a autonomia que marca sua influência no curso da história. Para Rémond "a política é a atividade que se relaciona com a conquista, o exercício, a prática do poder". Em sua opinião, o político não se relaciona apenas ao Estado, mas "ele se estende também às coletividades territoriais e a outros setores por esse movimento que ora dilata e ora encolhe o campo do político" ${ }^{14}$

Nessa mesma direção vinha trabalhando o geógrafo Claude Raffestin, cuja obra Pour une Géographie du Pouvoir, foi publicada em 1980. Seu ponto de partida é a critica à geografia política, que fez do Estado a única forma de organização dotada de poder político suscetível de se inscrever no espaço. Em sua opinião, a verdadeira geografia só pode ser uma geografia dos poderes, não se restringindo a uma concepção unidimensional do Estado. ${ }^{15}$ $\mathrm{Na}$ abordagem proposta por Raffestin, as categorias de espaço e tempo (lugar, duração e ritmo) são fundamentais na relacionalidade entre atores e para as estratégias que esses utilizam. As posições dos atores no espaço e no tempo são diferenciadas e a suas capacidades de poder e habilidades de utilizar suas posições e recursos disponíveis não são idênticas. Espaço

\footnotetext{
${ }^{12}$ Ibidem, p. 271.

${ }^{13}$ No Brasil, em 1994 foi publicado RÉMOND, René. Por que a história política? Estudos Históricos. Rio de Janeiro, 13 :7-19, jan-jun 1994; dois anos depois saiu RÉMOND, René (dir.). Por uma história política. Rio de Janeiro: Ed. UFRJ/Ed. FGV, 1996.

${ }^{14}$ Ibidem, p. 443-444.

${ }^{15}$ RAFFESTIN, Claude. Por uma geografia do poder. São Paulo: Ática, 1993. p. 22.
} 
e tempo funcionariam como ponto de apoio para se aplicar a alavanca que aciona o poder e por ali modifica as situações reais no sentido da finalidade pretendida. Como o poder se apoia sobre espaço e tempo, para se conseguir inteligibilidade seria preciso mostrar as diferentes situações espaciais e temporais dos atores em relação, identificando simetrias ou dissimetrias entre os polos. ${ }^{16}$

Nesse sentido, as referências a René Rémond e a Claude Raffestin contribuem para demonstrar a importância epistemológica das categorias de poder e ideologia e, ao mesmo tempo, pelo entendimento de se tratar sempre de uma problemática relacional, que envolve o tempo e o espaço. No objetivo de um diálogo interdisciplinar, concentraremos nossa atenção na nova geografia política, a partir da obra inauguradora de Raffestin. É preciso tomar a geografia para além da antiga consideração de disciplina auxiliar da história, trazendo conceitos que de fato proporcionem um diálogo epistemológico para a história ambiental.

O ponto de partida é a premissa proposta por Raffestin de que a abordagem relacional exige uma problemática muito diferente daquela que dominou o entendimento do espaço, ou seja, seria preciso superar a problemática morfofuncional que se fundamenta numa operação triangular: “querer ver, saber ver, poder ver". Para se romper com a narrativa e escala unidimensional do Estado seria preciso uma problemática relacional que superasse a concepção morfofuncional e postulasse outra geografia, que fosse comprometida com o "querer existir, saber existir, poder existir": seria necessário antes uma "problemática que torne inteligíveis não somente as formas investidas de poder, mas as relações que determinam as formas". ${ }^{17}$ Trata-se de uma mudança epistemológica radical, pois exige "outras interrogações e outras inquietações sociais que, num outro enfoque, se inscrevem num contexto que não é o da testemunha, mas sim o da "participação crítica"'. ${ }^{18}$

Um aspecto importante do seu pensamento é a relação estabelecida entre território, norma e recurso. Nas relações com os territórios ou com os recursos sempre estão presentes poder e norma para a maior eficácia do controle e da gestão dos seres e das coisas. Tratam-se de poderes, pois o poder político é congruente à toda forma de organização. Assim, critica a

\footnotetext{
${ }^{16}$ Ibidem, p. 34.

${ }^{17}$ Ibidem, p. 29.

${ }^{18}$ Ibidem, p. 31.
} 
premissa unidimensional do Estado como única forma de organização dotada de poder político suscetível de se inscrever no espaço. São as relações que tornam inteligíveis os poderes e suas manifestações espaciais. Os elementos constituintes da problemática relacional são: a) os atores, cada um com sua política; b) o conjunto das intenções (finalidades dos atores); c) as estratégias que os atores utilizam para alcançar suas finalidades; d) os diversos códigos utilizados pelos diferentes atores; e) os componentes espaciais e temporais da relação.

A crítica ao entendimento comum sobre o poder é crucial: poder não é coisa nem resulta da posse de coisa; também não vem de cima nem é unidirecional. o poder se manifesta na relacionalidade e se realiza de baixo para cima, isto é, se realiza no consentimento ou resposta positiva por parte daquele que é alvo da ação do poder. Dois outros entendimentos precisam ser considerados: poder é igual saber, ou seja, quem sabe tem poder e quem tem poder sabe; e como existe o poder também existe o não-poder (alienação). 0 poder visa dominação sobre seres e coisas e, para conseguir sua finalidade, na relação o poder pode privilegiar determinado trunfo (população, território e recursos) ou combinar diferentes trunfos, em graus diversos. A relação é fonte de modificação, ou seja, uma vez iniciada, os atores em todos os seus polos se modificam no curso do processo relacional. Daí Raffestin afirmar que somente "quando a relação se desvenda que se pode precisar, fazendose um orçamento relacional, quais são as estruturas do poder". ${ }^{19}$

No mesmo sentido é preciso criticar a noção do espaço como local onde estão as coisas e os seres e onde ocorrem os eventos. Como explica Manuel Castells, o espaço é "sempre conjuntura histórica e forma social que recebe seu sentido dos processos sociais que se expressão através dele". ${ }^{20}$ Henri Lefebvre considera o espaço produzido historicamente, logo se trata sempre de produção do espaço pelas sociedades ao se organizarem político, social, cultural e economicamente. Para o autor, portanto, o espaço é político e um produto social, sendo que "a prática espacial, as representações do espaço e os espaços de representação intervêm diferentemente na produção do espaço: segundo suas qualidades e propriedades, segundo as sociedades (modo de produção), segundo as épocas". ${ }^{21}$ Christian Schmid afirma que

\footnotetext{
${ }^{19}$ Ibidem, p. 64.

${ }^{20}$ CASTELLS, M. A questão urbana. 4. ed. Rio de Janeiro: Paz e Terra, 1983.

${ }^{21}$ LEFEBVRE, Henri. La Production de L'Espace. $4^{a}$ ed. Paris: Éditions Anthropos, 2000. LEFEBVRE, Henri. A Produção do Espaço. Trad. Grupo "As (im)possibilidades do urbano na metrópole contemporânea". Belo Horizonte, 2006, no prelo, p. 75-76. Disponível em http://www.mom.arq.ufmg.br/mom/arq_interface/1a aula/A_producao_do_espaco.pdf. Acessado em 9 de novembro de 2015.
} 
"Lefebvre constrói sua teoria da produção do espaço social e do tempo social a partir dessas suposições. De acordo com essa perspectiva, espaço e tempo não são puramente fatores materiais." ${ }^{22}$ Lefebvre não hierarquiza os três momentos (percebido, concebido, vivido) nem os vê como estáveis e simples. Conforme Alain Lipietz ${ }^{23}$ a questão não se restringiria aos conflitos que se dão no espaço, mas ao fato de o espaço ser o próprio objeto em disputa. "A estruturação do espaço é a dimensão espacial das relações sociais, e, sendo estas lutas de classe, a estruturação do espaço é lutas de classes, não somente no sentido de que ela é produto delas, mas no de que ela é o que esta em jogo e mesmo, um meio delas". o espaço é produzido e, ao mesmo tempo, o espaço é produto. Daí Castells afirmar ser o espaço "suscetível de produzir, em contrapartida, efeitos específicos sobre os outros domínios de conjuntura social, pela forma particular de articulação das instâncias estruturais que se constituem".

Raffestin parte da constatação de que as organizações são formadas de seres e coisas, que são seus trunfos. Ao movimentar-se e entrar em relação (agir), a organização decide colocá-los todos ou parcialmente no jogo relacional. O espaço é crucial para a estratégia dos atores, daí as organizações procurarem estabelecer posições vantajosas e controlar os circuitos para a circulação, distribuição e difusão ou, ao contrário, para concentração, circunscrição e rarefação da energia e informação. As organizações, no entanto, quase sempre mascaram seus verdadeiros trunfos. Nesse sentido, Doreen Massey está correta ao afimar que território e norma fazem parte do esforço dos atores para subjugar o espaço e, do mesmo modo, concebê-lo como "recorte estático através do tempo, como representação, como um sistema fechado, e assim por diante, são todos modos de subjugá-lo". ${ }^{24}$

Raffestin concentra-se em explicar a ação dos atores (organizações), que a partir do espaço, produz o território. Entretanto, ele observa que "o poder evolui sempre entre dois polos dos quais se serve sucessivamente: a unidade e a pluralidade". Ele pede ao leitor para não se esquecer da "lição da biologia: nossa riqueza coletiva está na nossa diversidade". Assim, o outro nos é necessário, seja indivíduo ou conjuntos coletivos, exatamente porque "é diferente de nós". Uma ciência que se concentrasse apenas no poder

\footnotetext{
${ }^{22}$ SCHMID, Christian. A teoria da produção do espaço de Henri Lefebvre: em direção a uma dialética tridimensional. GEOUSP - espaço e tempo, São Paulo, N³2, pp. 89- 109, 2012. Disponível em file:///C:/Users/ User/Downloads/74284-99838-1-PB\%20(1).pdf. Acessado em 10 de novembro de 2015.

${ }^{23}$ LIPIETZ, Alain. O capital e seu espaço. São Paulo, Nobel, 1988.

${ }^{24}$ MASSEY, Doreen. Pelo Espaço. Rio de Janeiro: Bertrand Brasil, 2008, p. 95; ver também p. 32-33 e 94.
} 
instituído (seja pró ou contra), não seria capaz de romper com a concepção morfofuncional para trazer para a existência o "querer existir, saber existir, poder existir". Para Raffestin a diversidade é uma "garantia da autonomia da espécie humana" e de sua "autonomia cultural, sem a qual não é possível uma ação diferenciada”. ${ }^{25}$ Massey vai mais longe, ao afirmar que o espaço é a possibilidade da emergência, existência e movimentação dos heterogêneos, que nas relacionalidades configuram diferentes espacialidades, conforme as múltiplas trajetórias coetâneas. "Conceituar o espaço como aberto, múltiplo e relacional, não acabado e sempre em devir, é um pré-requisito para que a história seja aberta e, assim um pré-requisito também para a possibilidade da política." 26

Para Raffestin o território é o espaço onde se projetou trabalho (energia e informação), tanto no sentido material como simbólico, e que "revela relações marcadas pelo poder". Espaço é um a priori que somente tem sentido como espaço relacional (espacialidade que o produz). Como explica Raffestin, "o espaço é anterior ao território" e, portanto, "espaço e território não são termos equivalentes". Ele chama o espaço de "prisão original", no sentido de que é um a priori que antecede a qualquer ação, porém "o território é a prisão que os homens constroem para si." ${ }^{27}$ Como explica David Sack, o território resulta da estratégia para "afetar, influenciar e controlar pessoas, fenômenos e relações”, por meio da delimitação de área. Portanto, uma determinada área se torna território se as fronteiras são usadas para moldar, influenciar, controlar atividades e comportamento ou para controlar o acesso. "As fronteiras de um território e os meios pelas quais elas foram comunicadas não são inalteráveis. [...] A maioria dos territórios tendem a ser fixos no espaço geográficos. Mas, alguns podem mudar..." 28

Massey contribui nessa questão, ao discutir a divergência entre as posições políticas dos que defendem fronteiras abertas e dos que pregam o fechamento das fronteiras. Ele relativiza e politiza a noção de fronteira. ${ }^{29} \mathrm{~A}$

\footnotetext{
${ }^{25}$ RAFFESTIN, op. cit, p. 130.

${ }^{26}$ MASSEY, op. cit., p. 95; ver também p. 32-33 e 93.

${ }^{27}$ RAFFESTIN, op. cit., p. 143-144.

${ }^{28}$ SACK, Robert David. Human Territoriality: Its Theory and History. Cambridge: Cambridge University Press, 1986, p. 20.

${ }^{29}$ Segundo Jöel Bonnemaison nem todo território de povos sedentários é fundado na fronteira, inclusive tem povos enraízados sem "linha de fronteira", mas com um núcleo central da vida coletiva, estendendo-se depois uma "zona de contornos fluidos", uma "zona-tampão": florestas, "lugares de inquietude", no qual se entra com muita precaução e raramente. "Um território é coisa bem diferente de um espaço fechado, protegido por uma fronteira. No fundo, ele é muito mais um 'núcleo' do que uma muralha, e um
} 
autora reconhece o direito de pessoas locais defenderem "seu próprio lugar local" com fronteiras, como uma inevitabilidade colocada pelo mundo no qual se vive. Para a autora, não se trata de um fetichismo do espaço, como se apresenta o debate entre estabelecer ou não fronteiras, como se houvesse oposição entre abertura espacial e fechamento espacial. A forma espacial não seria uma topografia universal com o qual se pudessem distinguir posições políticas, pois seria preciso considerar as circunstâncias históricas. "O debate sobre abertura/fechamento, em outras palavras, não deveria ser colocado em termos de formas espaciais abstratas, mas em termos das relações sociais através das quais os espaços e aquela abertura e fechamento são construídos, as sempre móveis geometrias de poder espaço-tempo." Para a autora, tratam-se de "práticas sociais espacializadas e relações e poder social". Portanto refere-se à tomada de posição política e não a "aplicação de uma fórmula sobre espaço e lugar". 30

O território é um determinado modo de subjugar o espaço, "é uma produção, a partir do espaço". Por ser uma produção, "se inscreve num campo de poder". Algumas categorias são fundamentais para se compreender o conceito de território: apropriação, delimitação, definição e regulação. $O$ ato de se apropriar do espaço se inicia "a partir do momento em que um ator manifeste a intenção de dele se apoderar”. Para Raffestin, produzir uma representação do espaço já é uma apropriação. Na obra do autor, a categoria "delimitação" ganha uma importância fundamental, pois ele considera a ação de fixar limite/fronteira um componente geral (universal) de toda prática, não somente a espacial. ${ }^{31}$ "Delimitar é, pois, isolar ou subtrair momentaneamente ou, ainda, manifestar um poder numa área precisa"..$^{32}$ Entretanto, não se pode atribuir ao autor uma posição rígida em relação à noção de fronteira, pois o ato de delimitar pode ser imposição de linha (linear) rígida, mas quase sempre trata-se de zona, isto é, a fronteira não termina abruptamente numa linha, mas constitui a zona de transição entre um nós e os outros, que se por um lado restringe/impede, por outro é espaço de troca/comunicação. Para Raffestin o território é indissociável da noção de limite/fronteira, pois toda organização delimita seu campo operacional onde efetivará sua ação.

tipo de relação efetiva e cultural com uma terra, antes de ser um reflexo de apropriação ou de exclusão de estrangeiro." BONNEMAISON, Jöel. Viagem em torno do território. In.: ROSENDAHL, Zeny; CORRÊA, Roberto Lobato (Org.s). Geografia Cultural: um século (3). Rio de Janeiro, EdUERJ, 2002, pp.83-131, p. 101.

${ }^{30}$ MASSEY, op. cit., p. 234-235.

31 "Definir, caracterizar, distinguir, classificar, decidir, agir implicam a noção de limite: é preciso delimitar."

${ }^{32}$ Fixar objetos da ação já constitui uma "delimitação em relação a outros objetivos possíveis". RAFFESTIN, op. cit., p. 153. 
“O território se forma a partir do espaço, é o resultado de uma ação conduzida por um ator sintagmático (ator que realiza um programa) em qualquer nível. Ao apropriar de um espaço concreta ou abstratamente (por exemplo, pela representação), o ator 'territorializa' o espaço." ${ }^{33}$

Estabelecer limites é um processo de regulação, sendo a norma uma dimensão indissociável do território, visto esse ser sempre um espaço normado pelo poder que se instala e o governa (não apenas o Estado nem é questão institucional, mas de efetiva capacidade de exercer o poder). No território estão presentes as dimensões normativas, simbólicas, materiais, seja em uma, algumas ou todas as esferas da vida humana: sociais, econômicas, culturais, políticas, técnicas e ambientais.

$\mathrm{Na}$ definição de territorialidade proposta por Raffestin se encontra a questão da relação com a natureza, cujas implicações têm merecido pouca atenção dos que utilizam a citação que segue abaixo. As relações sociais têm retido a atenção dos estudiosos ou daqueles que aplicam a territorialidade em programas e políticas públicas, tendo como referência a definição proposta por Raffestin. Entretanto, a variável negligenciada ocupa um lugar central na sua reflexão, pois a quarta parte do livro "Por uma Geografia do Poder" é toda dedicada a analisar a relação dos atores/sociedade com a natureza. ${ }^{34}$

De acordo com a nossa perspectiva a territorialidade adquire um valor bem particular, pois reflete a multidimensionalidade do "vivido" territorial pelos membros de uma coletividade, pelas sociedades em geral. Os homens "vivem", ao mesmo tempo, o processo territorial e o produto territorial por intermédio de um sistema de relações existenciais e/ou produtivistas. Quer se trate de relações existenciais ou produtivistas, todas são relações de poder, visto que há interação entre os atores que procuram modificar tanto as relações com a natureza como as relações sociais. (O negrito é nosso) ${ }^{35}$

Segundo Raffestin, para os atores sintagmáticos ${ }^{36}$ (Estados, empresas, organizações, proprietários fundiários etc.), a natureza é matéria, que a

\footnotetext{
${ }^{33}$ Ibidem, p. 143.

${ }^{34}$ Ibidem, pp. 223 e seguintes.

${ }^{35}$ Ibidem, p. 158-159.

${ }^{36}$ Raffestin define como ator sintagmático aquele age para realizar programa (tem finalidade, estratégia, códigos e trunfos espaço-temporais, que mobiliza parcial ou integralmente). 0 conceito de ator sintagmático manifesta a ideia de processo e articulação sucessiva no interior do processo, com vista a atingir a finalidade conforme a intenção ou interesse do ator. Ator sintagmático está engajado num complexo jogo relacional e, no processo, ele se desenvolve e cresce somente a partir das relações. A organização, da família ao Estado, combina toda espécie de elementos para produzir uma ou várias coisas; articula momentos diferentes da realização do seu programa pela integração de capacidades múltiplas e variadas. Planejamento, Programa, Projeto e Plano são partes integrantes do vocabulário dos atores sintagmáticos. RAFFESTIN, op. cit., p. 40-41.
} 
semelhança do espaço, forma um a priori que será objeto da manipulação do poder, dentro de um conjunto de possibilidades presente em determinada circunstância histórica. Daí, ele iniciar a discussão com uma crítica à noção largamente aceita de recurso natural. Sua ideia central pode ser resumida na citação: “... é uma concepção histórica da relação com a matéria que cria a natureza sociopolítica e socioeconômica dos recursos. 'Os recursos não são naturais; nunca foram, e nunca serão!'” ${ }^{77}$ Recurso natural, portanto, surge da relação historicamente determinada e espacialmente localizada, mediada por um sistema socioeconômico, sociocultural, sociopolítico e técnico. A natureza é igual matéria, que é igual espaço, ou seja, não tem significado em si mesma, exceto ser o que é. (Não se trata de um reducionismo, mas de se chegar à inteligibilidade da categoria recurso natural como relacionalidade socioterritorial, tendo em visto não estar em questão a importância crucial da diversidade da natureza e da vida). A distinção entre matéria e recurso é decisiva, sendo a primeira um dado natural e a segunda uma realidade histórica.

A relação com a natureza, que a modifica para recursos, é mediatizada pelo território por meio de diversos mediadores combinados: técnica (capacidade de manipular as propriedades identificadas); sociocultural (demanda por essas propriedades), econômica (capacidade de transportar, produzir e fazer circular para o consumo); e político-jurídica (norma jurídica estabilizadora da posse da coisa, domínio/propriedade absoluta e controle do acesso às fontes, bem como poder político monopolizando a força capaz de assegurar esse direito). O contexto técnico-econômico deve ser considerado, pois o número de propriedades correlativas às classes de utilidade pode crescer com o tempo, conforme a técnica avança e as outras circunstâncias históricas se modificam (econômica, social, cultural, jurídica ou política). 0 inverso também pode ocorrer, pois as mudanças podem provocar redução ou desaparecimento de certas propriedades, por não apresentarem mais interesse ou utilidade.

A técnica pode ser simétrica: relação não destrutiva com o meio material (natureza); ou dissimétrica: relação destrutiva com o meio material. A sociedade atual tem uma tecnicidade dissimétrica, prevalecendo a tendência de faltar certas matérias num futuro mais ou menos próximo. A fragilidade aumenta com o crescimento da complexidade da técnica, pois a mudança, mesmo que mínima, pode gerar consequência no conjunto. ${ }^{38}$ Recorrendo a

\footnotetext{
${ }^{37}$ Ibidem, p. 225

${ }^{38}$ RAFFESTIN, op. cit., p. 227-228.
} 
Ricardo Antas Jr., existe uma relação epistemológica entre técnica e norma, pois ambas promovem condicionamentos e determinam o funcionamento socioterritorial. ${ }^{39}$ Como afirma Milton Santos, as técnicas são dimensões normativas específicas que atribuem rigidez às formas espaciais e ordenam o espaço, tendo alcançado no atual estágio técnico-científico crescente rigidez normativa, particularmente por meio dos objetos técnicos. ${ }^{40}$

Raffestin explica que a técnica pertence à esfera do poder, exprime relações de poder entre os homens para os quais as propriedades da matéria são trunfo. "A produção dos recursos supõe, pois, uma dominação mínima de uma porção do quadro espaço-temporal dentro do qual, e para o qual, a tecnicidade interage com a territorialidade". ${ }^{41}$ Toda relação com a matéria é uma relação com o espaço e com o tempo e, portanto, é crucial a questão do controle do acesso ao espaço e da duração. ${ }^{42}$

Raffestin estruturou o livro "Por uma Geografia do Poder", conforme entende os trunfos do poder: população-território-recursos. Essas são as três partes com as quais constrói sua tese de que a geografia não se reduz à unidimensionalidade do Estado e que se requer uma problemática relacional para se passar de uma triangulação morfofuncional para uma nova geografia do poder. Para o autor, as três categorias (população-território-recursos) formam um sistema que precisa ser interrogado em suas "ordens" e enquadramentos. Se para a geografia, conforme Raffestin conclui no final do livro, a tarefa é "enfrentar aquilo que se convencionou chamar de 'atualidade' aparentemente incoerente e incompreensível” ${ }^{43}$, para a história ambiental o desafio seria introduzir a categoria poder e a problemática espacial nos estudos históricos.

\section{Problemática da escala, do tempo e dos agenciamentos.}

A perspectiva ambiental da historia não é capaz de evitar por si mesma as contradições entre escalas, que levam à generalização de casos individuais (atomismo), juízos de valores (generalizações) e lacunas. A

\footnotetext{
${ }^{39}$ ANTAS JR., Ricardo M. Território e Regulação. São Paulo, Associação Editorial Humanas: FAPESP, 2005, capítulo 2 .

${ }^{40}$ SANTOS, 1996, op. cit., p. 152.

${ }^{41}$ RAFFESTIN, op. cit.. p. 227-228.

${ }^{42}$ Raffestin menciona como exemplo a crise do petróleo de 1973, quando a OPEP buscou controlar o espaço petrolífero e controlar a duração (quantidade extraída e comercializada). As novas relações de poder inauguradas com a crise do petróleo afetaram a tecnicidade dos países consumidores.

${ }^{43}$ RAFFESTIN, op. cit., p. 269.
} 
amarração da história acaba sendo o recurso narrativo a partir da tese e do enredo pré-estabelecido. 0 ambiente não é categoria suficiente se não considerar criticamente a problemática espacial, pois poderia ficar refém da concepção corrente do espaço como dado e do nacional-estatal com escala. Uma nova imaginação e atitude sobre o espaço, como aberto, relacional, processual e de múltiplos devires, capaz de reconhecer aos outros as vidas que lhes são próprias, ${ }^{44}$ que considera as diferenças de escala e o conceito de multiterritorialidade ${ }^{45}$ poderia oferecer uma crítica consistente á concepção unidimensional da escala territorial do Estado. Como exemplo, penso no termo neobrasileiro utilizado por Darcy Ribeiro, na obra "O Povo Brasileiro". ${ }^{46}$ Esse termo expressa um equívoco, criado pela armadilha da escala nacional estatal, pois preconcebe a existência do Brasil e do brasileiro anterior à sua própria existência. Ao reproduzir "a invenção da nacionalidade", valida uma historia "estatal". A expressão natureza brasileira participa do mesma ideia de um destino manifesto, dado desde a origem, que resultou no Brasil e em sua evolução até o presente. Expressa uma apropriação e relações de poder por parte de uma categoria que se sobrepôs e sobrecodificou o que existia anteriormente. A construção discursiva bebe na utopia que pressupõem o Brasil já existente.

Nós, historiadores ambientais, temos usado o termo humanos e não-humanos nos nossos trabalhos. A questão de se considerar o não-humano como agente é uma simplificação da complexidade muito refinada e complicada da natureza, com diferenciações múltiplas e delicadas. Dizer que os processos biogeográficos resultam de agentes naturais, no sentido de agenciamento, implica aceitarmos existir intencionalidade e finalidade, que se realiza por meio de estratégia. Essa transposição do conceito de agente para os "não-humanos" se reporta a uma complexa discussão que deseja negar o processo que está na origem da noção de natureza como objetividade "privada de todo significado, como domínio de fatos neutros opostos a nossos valores subjetivos, que se liga ao surgimento da moderna ciência natural e,

\footnotetext{
${ }^{44}$ MASSEY, op. cit., p. 245.

${ }^{45}$ HAESBAERT, Rogério. 0 mito da desterritorialização: do "fim dos territórios" à multiterritorialidade. 3 ed. Rio de Janeiro: Bertrand Brasil, 2007.

${ }^{46}$ Como não se fascinar com a expressão de Darcy Ribeiro, em "O Povo Brasileiro", referindo-se à "criação do Brasil”, onde existiam verdadeiros "criatórios de gente”. Essa escrita produz uma absoluta homogeneidade que é o "povo brasileiro", independente de o autor ter como objetivo defender a diversidade, pois essa se torna apenas variações de uma totalidade pré-concebida. RIBEIRO, Darcy. O Povo Brasileiro. SP: Companhia das letras, 1995.
} 
ao mesmo tempo, à economia mercantil que desemboca no capitalismo. ${ }^{47}$ Substituir a visão da natureza objeto pelo princípio de que os não-humanos interferem nos processos históricos e geográficos é uma necessidade que provém da consciência ambientalista e ecológica que se fortaleceu a partir da década de 1960. A questão aqui não é negar simplesmente, mas firmar a necessidade da demonstração da complexidade envolvida nos processos naturais.

A variável natureza dentro de um dado processo social contribui para especificar a configuração espacial concreta dos fenômenos sociais, mas daí não se sustenta afirmar que se trata de agenciamento. $O$ agente é portador de intencionalidade (querer e buscar intencionalmente uma finalidade) que são propriedades humanas. Não se deve confundir com agenciamento supostas correlações de causa e efeito, ação e reação, ou emergências complexas, pois não faria sentido epistemológico se consideramos os conceitos de autopoiesis e auto-organização, de Maturana e Varela, ${ }^{48}$ e a teoria da complexidade. ${ }^{49}$ Outro problema é tomar posições ideológicas ambientalistas e transpô-las como interpretação histórica, tais como a supervalorização do conhecimento etnobotânico das comunidades tradicionais. Assim, o historiador ambiental deve ter o cuidado, em função de sua posição ambientalista, principalmente com o uso de adjetivos e a formulação de juízos de valor.

Outra crítica ao que fazemos como história ambiental se relaciona às afirmações de obviedades, especialmente com base em "cientificismo" comum aos ambientalistas militantes. Se isso é um recurso mais do que necessário à luta política, nos cabe como historiadores ambientais dar sustentação epistemológica. Ao usar outras ciências, particularmente as de outra classe de conhecimento (biológico, geológico, agronômico etc.), ou outros saberes que não os acadêmicos, não podemos reduzir de modo simplista, pois o diálogo de saberes requer rigor, inclusive em relação às tradicionais ciências auxiliares da história, tais como a geografia, economia, sociologia. Termos que são conceitos espaço-temporalmente determinados e respondem a códigos que lhes são específicos devem ser transpostos com o máximo cuidado,

\footnotetext{
${ }^{47}$ ZIZEK, Slavoj. Vivendo no fim dos tempos. São Paulo, Boitempo, 2012, p. 176.

${ }^{48}$ MATURANA, Humberto; VARELA, Francisco. A árvore do conhecimento: As bases biológicas da compreensão humana. São Paulo: Palas Athena, 2001.

49 “'A teoria da complexidade defende que se tenha um método capaz de articular aquilo que está separado e unir aquilo que está dissociado, que seja capaz de detectar e não ocultar as ligações, as solidariedades, as implicações, as interdependências e as complexidades, que recuse o discurso linear, como ponto de partida e fim, e a simplificação abstrata." FONSECA, Alexandre Torres. História da história: a big history e a transdisciplinaridade. Belo Horizonte: UFMG, 2007. (Tese de Doutorado).
} 
como nos exemplos: sistemas técnicos, objetos técnicos, ação social, tecnologia, reprodução ampliada, regime de relações, reprodução econômica, reprodução cultural, entre outros.

A história ambiental, ao fazer uma releitura da documentação, com o olhar voltado para o ambiente, conscientemente ou não, trabalha com a grande escala, ou seja, com contextos locais (atores) que protagonizaram os fenômenos socioespaciais, mais especificamente, socioambientais. Generalizar para o "Brasil" é passar da grande escala para a pequena escala (nacional-estatal), ou seja, inferir de conjuntos atomistas (heterogêneos) conjuntos coletivos (homogêneos). o mecanismo de generalização, a partir das ocorrências localizadas (casos locais), possui uma margem grande de risco, pois a mudança de escala afeta a natureza dos fenômenos e, consequentemente, mudanças de escala podem resultar em erro, mesmo que aparentem coerência. Como afirma Racine et. alii, o risco de inferir relações de uma para outra escala pode produzir conclusões falaciosas, isso porque "as coordenadas necessárias à localização dos eventos modificam-se de acordo com a escala em que os eventos são analisados". ${ }^{50}$

Quando se transpõe ocorrências atomistas aprendidas em suas circunstâncias locais (monografias locais, história local, história regional, micro-história etc.) para a dimensão nacional-estatal se muda da grande escala para a pequena escala. Os estudos sobre escravidão servem para exemplificar a questão: a historiografia produzida em Minas Gerais, nas últimas três décadas, tem contrariado as interpretações dominantes para o "Brasil”, centradas na categoria Plantation. A preocupação deve ser ainda maior para os fenômenos socioambientais, que são quase sempre manifestações de ocorrência na grande escala, ou seja, localizadas territorialmente; ou são fenômenos naturais e diastrofismo produzidos por processos tectônicos (tais como clima, dispersão de espécies, invasões biológicas etc.), ou fenômenos de ordem da cultura material (tais como a difusão do trigo, milho, mandioca, gado vacum etc.), ou culturais (como as representações da natureza), cujo sentido e abrangência requerem pequena escala e longa duração. Como explica Boaventura Santos, diferentes fenômenos e suas circunstâncias não podem ser representados igualmente em todas as escalas e é por isso "que as diferenças de escala apesar se serem, na aparência, quantitativas, sejam, na realidade, qualitativas". Generalizar ocorrências locais para uma área cres-

\footnotetext{
${ }^{50}$ RACINE, J. B., RAFFESTIN, C., RUFFY, V. Escala e ação, contribuição para uma interpretação do mecanismo da escala na prática da Geografia. In. Revista Brasileira de Geografia. Rio de Janeiro, IBGE, 1983 , vol. 1, no .45 , mar. 1983, p. 127.
} 
centemente maior é promover mudanças de escala. Uma mudança de escala pode provocar alterações, especificamente quando se refere a fenômeno representável apenas em determinada escala. ${ }^{51}$

Brasil é uma escala que corresponde a determinada ou várias entidades coletivas abrangentes, (história, geografia, política, sociedade, economia, cultura, arte e território nacional; povo, nação e Estado brasileiro) construídas no campo das ideias e na prática, consideradas separadamente ou agrupadas em partes ou todas juntas. Como entidade coletiva produziu e, ao mesmo tempo, foi o produto da escala estatal-nacional que se impôs na segunda metade do século XIX, obtida por um processo de escolhas entre o que existiria e o que ficaria de fora (esquecimentos) no seu processo de construção. Em toda prática intelectual essa operação de "esquecer" é necessária, quando se passa da grande escala para a pequena escala, porém, a questão é saber os níveis de coerência e aderência das correlações e generalizações que são realizadas, bem como se essas estão explicitadas ou se escamoteia intencionalidades do poder.

O princípio da coerência é fundamentalmente um problema de escala, porque ao se enquadrar áreas maiores torna-se necessário aglutinar atomismos (localismos) para formar entidades coletivas. Entretanto, a linha divisora entre uma operação técnica ou ideológica é muito tênue, mesmo que tenhamos que concordar com Pierre Bourdieu que a busca de critérios objetivos não muda, em última instância, o fato de serem "objetos de representação mentais", visto serem atos humanos..$^{52}$ A questão refere-se, portanto, à intencionalidade: a quem se destina. Para o campo acadêmico, como afirma Racine et. alii. a "correlação é sem dúvida o nó da questão", na passagem do "conjunto composto de elementos heterogêneo" para o homogêneo.

\footnotetext{
Haverá esquecimento consciente de uma multidão de detalhes que descobriremos no momento do trajeto real. A escolha de um subconjunto é necessária, primeiro porque é impossível fazer uma descrição exaustiva e depois porque. . . impossível memorizar uma tal descrição.

Como primeira aproximação pode-se, pois, definir a escala como uma função do esquecimento coerente que permita uma ação bem sucedida. A escala aparece desde então como um filtro que empobrece a realidade, mas que preserva aquilo que é pertinente em relação a uma dada intenção. ${ }^{53}$
}

\footnotetext{
${ }^{51}$ Esse é o caso do clima (pequena escala) e dos processos erosivos (grande escala). SANTOS, Boaventura de Sousa. op. cit., p. 144.

${ }^{52}$ BOURDIEU, P. O poder simbólico. Rio de Janeiro, Bertrand, 1985, p. 112.

${ }^{53}$ RACINE, J. B., RAFFESTIN, C., RUFFY, V. op. cit., p. 128.
} 
A questão é saber qual o Brasil ou a América Latina (territórios construídos no campo intelectual e no campo prático) o historiador ambiental tem em mente, pois quaisquer que sejam, resultaram de processos intencionais de "esquecimentos", conseguidos pela mediação possibilitada pela escala. "A questão que se coloca então é saber se, ao passar de uma escala a outra, as modificações na natureza ou na medida da dispersão serão previsíveis." ${ }^{54}$ Em relação ao Brasil, para períodos anteriores a 1930, nos quais não havia mercado interno nacional nem integração de comunicações e uma ordem pública nacionalmente unificada, não basta apenas somar ocorrências de diversos lugares para se inferir uma condição geral. É grande o risco de se produzir conhecimento de uma totalidade arbitrária que serve a determinada interpretação no jogo relacional do poder.

Racine et. alii, ao se referirem à mediação entre duas escalas, seja para atender o ator que busca agir ou para o pesquisador que deseja saber, chamam a atenção para o fato de ser "sempre sustentada, quer queiramos ou não, por uma relação de poder que mantemos com o território". ${ }^{55} \mathrm{~A}$ literatura social e historiográfica, pelo menos uma parte considerável, produzida na primeira do XX, foi tributária da concepção de um Brasil pré-existente, portanto de um mito unitário que se impôs como limite capaz de enquadrar as diferentes narrativas. ${ }^{56}$ Isso porque o "existir" e o "esquecer" são mecanismos indissociáveis das relações de poder, tanto para os atores que produziram as fontes como para o pesquisador que as utilizam.

A principal dificuldade para se escrever uma história de entidades gerais (Minas Gerais, Brasil, América Latina, Ocidente, Mundo) é que essas pedem consideração pelas questões espaço-temporais, além de demandar uma análise do poder, minimamente necessária para orientar a escrita e evitar as armadilhas ideológicas criadas pelas distorções escalares. O problema de uma história de entidade geral é que essa não se sustenta apenas somandose exemplos e casos locais. Para uma história local, no qual se tem mais controle sobre as variáveis, os exemplos constituem um recurso explicativo importante, especialmente pela função didática que desempenham. Passar da história local/regional para a nacional ou geral, chegando mesmo a uma Big History, traz inúmeras complicações para o historiador, especialmente no campo da história ambiental. No caso de uma história de entidade geral, pode

\footnotetext{
${ }^{54}$ Ibidem., p. 125.

${ }^{55}$ Ibidem, p. 130.

${ }^{56}$ ESPINDOLA, op. cit. p. 194-202.
} 
ser apenas uma tautologia, ou seja, repetições com objetivo de se reafirmar. "Vejam! A tese está correta." Pode não passar de somatórios arbitrários descontextualizados das circunstâncias históricas que produziram os casos individuais (atomismos).

A problemática da escala para a história ambiental é crucial, visto que seu objeto ambiental tem forte enraizamento local e expressa fenômeno socioespacial. Por outro lado, determinados fenômenos naturais são ocorrências que abrangem áreas enormes, até mesmo todo Planeta, além de se movimentarem e se modificarem no processo de sua realização. Nos dois casos, fenômenos de grande escala (ocorrência em áreas pouco extensas e restritas) e de pequena escala (ocorrência em áreas de grande extensão e irrestritas), a transição de uma para outra e as generalizações são difíceis, pois se trata de fenômenos próprios a cada escala. A exigência de rigor analítico e conceitual cresce consideravelmente à medida que se diminui a escala para abranger áreas maiores. A projeção do local para níveis mais gerais precisa considerar rigorosamente se não se trata de situações atomistas (multiplicidades de fenômenos locais), possivelmente circunstanciais e territorialmente localizadas. A transposição não deve resultar apenas de escolhas para corroborar uma determinada tese ou confirmar hipótese pré-estabelecida, pois isso não se sustenta epistemologicamente. Para a luta política o efeito retórico pode ser forte, quando se carrega na cor de determinada imagem, sem questionar a escala, porém o efeito desejado no jogo relacional do poder pode se esvair na primeira contraprova.

\section{História Ambiental: diálogo entre o tempo e a escala}

A história ambiental precisa considerar a dimensão espacial das relações das sociedades com a natureza, pois essas possuem dimensão socioespacial e ocorrem em campos operatórios que lhes são particulares, isto é, nunca são generalizados e universais. Estão conformadas por determinados sistemas de limites/fronteiras que delimitam áreas de existência das entidades e ocorrência dos fenômenos (campo de pertinência das entidades e fenômenos). Como afirma Raffestin, nenhuma sociedade, por mais elementar que seja, escapa à necessidade de organizar o campo operatório de sua ação. ${ }^{57}$ Isso tem implicações metodológicas porque introduz a problemática da escala na pesquisa, como observam Racine et. alii.:

${ }^{57}$ RAFFESTIN, op. cit., p. 150. 
Colocar o problema da escala é também colocar o problema da pertinência da ligação entre uma unidade de observação e o atributo que associamos a ela. Em qual escala, por exemplo, as unidades possuem propriedades globais? Muitos estudos empíricos têm demonstrado que pode haver propriedades globais em níveis diferentes. Cada estudo merece ser colocado dentro de sua perspectiva correta, isto é, dentro de seu campo de pertinência, não somente em relação à área escolhida, mas também em relação ao tipo de dados utilizados na análise. ${ }^{58}$

A espacialidade dos fenômenos não é aleatória nem se reduz ao social, mas apresenta materialidade formada pela matéria e pelos artefatos (cidades, infraestruturas de comunicação e energia, fábricas etc., isto é, os conjuntos de sistemas de objeto indissociáveis de correspondentes sistemas de ações). Também apresenta a materialidade formada pelo meio ambiente (paisagens humanizadas, ${ }^{59}$ ou seja, propriedades naturais modificadas pelos seres humanos; e propriedades naturais, tais como geologia, geomorfologia, clima etc.). A espacialidade criada pelos elementos materiais e não-formais configuram o espaço, produzindo enquadramentos que o organizam, a partir de lógicas determinadas pela extensão dos poderes que o produzem. $\mathrm{Na}$ verdade, o espaço como possibilidade de todo existente abarca sobrepostos ou justapostos muitos, múltiplos e plurais, combinados e desencontrados, de diferentes extensões, desde o local restrito em si mesmo (localismoatomista); o local que projeta sua extensão para além do seu ponto de origem; o espaço abrangente, cuja área se estende e pode chegar ao global; o espaço reticular criado pela ligação ponto a ponto possibilitados pelos objetos técnicos.

Cada categoria de espaço (espaço geográfico, território, região, lugar, paisagem e ambiente) possui uma ou várias dimensões escalares e, consequentemente, demanda a identificação correta das escalas de análise. Isso é válido tanto para o pesquisador realizar as observações e as demais etapas

\footnotetext{
${ }^{58}$ RACINE, J. B., RAFFESTIN, C., RUFFY, V. op. cit, p. 125.

${ }^{59}$ A paisagem pode ser compreendida como a conjunção de elementos naturais, técnicos, socioeconômicos e culturais. É importante, no entanto, considerar que a paisagem também é uma construção cultural e que existe um discurso escrito sobre a paisagem. A ideia de paisagem associa-se a sensação de lugar, a uma visão histórica da estética da natureza; uma literatura da paisagem; paisagem como ideologia - rustica, selvagem, degradada, bucólica etc.; a paisagem pintada. A noção de paisagem surgiu historicamente no contexto do renascimento e se constituiu nos tempos modernos. Por outro lato, cresceram as ideias sobre conservação da natureza, ao longo do século XX, tendo a noção de ambiente emergido com força na década de 1960, a partir da obra "Primavera Silenciosa" de Rachel Carson, publicada nos EUA, em setembro de 1962. O adjetivo ambiental ganhou crescente importância nas últimas cinco décadas: a busca do entendimento da relação entre economia e natureza; as raízes da ecologia; a crise ambiental; o surgimento de uma imaginação ecológica, a ética e direito ambiental, entre outras questões.
} 
da investigação científica, como também é desse modo que os atores procedem ao agirem com vista a realizar suas finalidades. A grande escala permite observar em detalhe o onde vivem, pensam e operam os atores locais; por sua vez o pensamento analítico se utiliza da pequena escala, da mesma maneira que os atores nacionais e os atores mundiais das redes que comandam os grandes investimentos de capital. As relações possuem forma e conteúdos determinados pela extensão das relacionalidades que abrangem. A introdução em áreas específicas de processos (econômicos, sociais, culturais e/ou políticos) vinculados à pequena escala tende a romper as limitações localistas anteriores para subordinar o local às relacionalidades criadas pelas novas implantações. "Nesse caso, o campo operatório da relação é, portanto, delimitado não somente pelos protagonistas imediatos, diretamente envolvidos, mas ainda pelas organizações que interferem com uma série de restrições a serem observadas". ${ }^{60}$

Nos dois últimos séculos, escala nacional-estatal se constituiu como uma narrativa hegemônica capaz de modificar o sentido, significado e reconhecimento de outras narrativas anteriores, reescritas conforme diferentes enquadramentos: nacional, folclórica, regionalista, pitoresca, excêntrica, divisionista, separatista, entre outras. A narrativa nacional-estatal se tornou absoluta e totalizadora. Isso pode ser negado, porém, a simples negação não modifica o fato de esse entendimento ter se tornado "naturalmente" auto-evidente, dominando nossa imaginação do espaço: está presente no adjetivo brasileiro ou nacional posto depois de natureza, cultura, interesse, economia etc. Essa construção tempo-espacial da modernidade subordinou o espaço ao tempo (narrativa), como afirma Boaventura Santos, ${ }^{61}$ condicionando o nascimento tanto da história como da geografia. 0 tempo linear foi estatizado e a seta do tempo apontou para progresso, fazendo da mudança uma lei inexorável, seja no pensamento liberal ou na crítica de esquerda. 0 século XX marca a vitória do tempo sobre o espaço: a narrativa enquadra e projeta um único tempo e o ideal da modernidade: civilização, ciência e progresso. 0 enredo da escrita da modernidade rejeitou os múltiplos e heterogêneos que poderiam solapar a unidade da narrativa do progresso. 0 espaço foi naturalizado, nacionalizado e convertido no quadro geográfico no qual ocorre o que realmente importa - a narrativa, não todas narrativas, mas a narrativa estatal-nacional. o tempo se tornou mudança e abertura

\footnotetext{
${ }^{60}$ RAFFESTIN, op. cit., p. 33.

${ }^{61}$ SANTOS, Boaventura de Souza. op. cit.
} 
para um futuro novo. Contra isso Doreen Massey se manifesta: "Se o tempo deve ser aberto, então o espaço tem de ser aberto também." 0 espaço aberto e relacional, como já foi dito, seria um pré-requisito de uma história aberta e também um pré-requisito "para a possibilidade da política". ${ }^{62}$

Qual a implicação desse programa intelectual proposto por Massey? Primeiro, romper com a narrativa centrada no Estado ou narrativas totalizadoras, cujo propósito é impor um sentido ao mundo, um fechamento do espaço. Em segundo lugar, ao se referir ao espaço como "possibilidade da política", pode-se associar ao sentido dado por Hannah Arendt à política: possibilidade do plural e convivência dos diferentes. ${ }^{63}$ Essa proposição se contrapõe ao domínio da metáfora temporal, que ao enquadrar o espaço e fechá-lo numa única dimensão escalar, fez da natureza objeto do poder soberano e sujeitou as várias temporalidades à unicidade temporal, cujas partições são períodos da história estatal-nacional como entidades existentes mesmo antes de existirem. Também contraria a lógica da modernidade que fez do espaço fixo, coisa e mercadoria, condição para a própria natureza se tornar objeto da economia, subordinando-o ao tempo/mudança/progresso, ou seja, à história numa única escala. Ao se imaginar o espaço como propõe Massey, se estará, de fato, abrindo-o às possibilidades da ação política e, ao mesmo tempo, a possibilidade de descoisificar a natureza. No sentido de a força coercitiva de enquadramentos nunca ser suficientemente forte para impedir a existência dos múltiplos e heterogêneos, bem como para impedir a emergência do não programado, não previsto e não desejado. No que se refere aos homens e mulheres, pessoas de carne e osso, como afirma Arendt: "a degradação da política como meio de atingir outra coisa jamais chegaram a suprimir a ação, a evitar que ela continuasse a ser uma das mais decisivas experiências humanas". ${ }^{64}$

Cabe ao pesquisador comprometido com uma problemática relacional fazer emergir esses existentes, desvelando a multiterritorialidade em que se desdobra o vivido espacial, nas suas diversas dimensões. Assim, imaginar o espaço como aberto e relacional é trazer à existência as múltiplas escalas, os outros, as autonomias e diferentes trajetórias, como a própria condição para as ações políticas afirmativas; significa também reconhecer trajetórias daqueles que foram colocados na invisibilidade pela ordem estabelecida ou, até

\footnotetext{
${ }^{62}$ MASSEY, op. cit., p. 94-95.

${ }^{63}$ ARENDT, Hannah. A Condição Humana. Rio de Janeiro:Forense Universitária, 1983, p. 220-224..

${ }^{64}$ Ibidem, p. 242.
} 
mesmo, daqueles que optaram por vontade própria por ficarem invisíveis à ordem estabelecida. Assumir uma nova imaginação do espaço é promover um entendimento totalmente diferente da realidade: "Trata-se do espaço como a esfera de uma simultaneidade dinâmica, constantemente desconectada por novas chegadas, constantemente esperando por ser determinada e, portanto, sempre indeterminada pela construção de novas relações", ${ }^{65}$ não são apenas pelos processos socioespaciais, mas também pelos processos naturais alheios aos humanos.

Imaginar o espaço relacional e aberto exige reconhecer que os processos sociais, os processos naturais (clima, geologia, plantas, animais, insetos e micróbios; taxas de reprodução de organismos e sucessos reprodutivos e fracassos etc.) e a interação entre eles não respondem as mesmas escalas e aos mesmos tempos, mas formam múltiplas escalas e diferentes estratos de tempo. Essa compreensão tem como consequência a negação das teses criadas pela narrativa unidimensional de entidades gerais totalizadoras, entre as quais a mais poderosa foi a nacional-estatal. Em relação ao tempo, Reinhart Koselleck pode ajudar com sua teoria dos estratos do tempo. "Os tempos histórico consistem em vários estratos que tem uns aos outros, mas que não dependem completamente uns dos outros". ${ }^{66}$ Em sua opinião, essa teoria pode ser muito útil pela "capacidade de medir diferentes velocidades, acelerações ou atrasos, tornando visíveis os diferentes modos de mudança, que exibem grande complexidade temporal". Considerando o que foi dito anteriormente sobre o espaço, pode-se afirmar que os diferentes estratos do tempo, com suas durações e ritmos próprios, se inscrevem na extensão compondo diferentes espacialidades. Essas inscrições formam a paisagem, que assim testemunham a complexidade da configuração espacial.

A paisagem como documento dessas inscrições apresenta diferentes níveis de visibilidade e, até mesmo, partes invisíveis, podendo ser observada pelo olhar curioso do turista ou demandar grande esforço de observação analítica por parte do pesquisador treinado. Entretanto, não é apenas uma questão de treinamento de observação, mas também de concepção de mundo e imaginação espacial, do observador disposto a trazer para a existência o "quer existir, sabe existir, pode existir", nos termos propostos por Raffestin, já mencionados antes. A paisagem contém diferentes inscrições em

${ }^{65}$ MASSEY, op. cit.., p. 160.

${ }^{66}$ KOSELLECK, Reinhart. Estratos do tempo: estudos sobre história. Rio de Janeiro: Contraponto: PUC-Rio, 2014, p. 19-20. 
múltiplas combinações de espaço-tempo, que servem de suporte, expressão e revelam as múltiplas trajetórias coetâneas. As trajetórias referem-se aos processos e relações socioespaciais, que são produzidas e vivenciadas pelos agentes concretos do sistema social. Uma determinada trajetória pode ou não envolver ou se chocar com outras, porém no primeiro caso será sempre relacionalidades entre atores sintagmáticos e envolverá atores pragmáticos. ${ }^{67}$ Com as trajetórias humanas dependem de suportes espaciais e se combinam ou se conflitam com as trajetórias do mundo natural, é preciso considerar a configuração natural complexa interagindo, integrando e interferindo nas trajetórias humanas.

As múltiplas trajetórias coetâneas podem se encontrar e se hibridizar; ou serem sobrepostas e sobrecodificadas para serem dominadas ou absorvidas, mas que sempre deixam traços de sua existência anterior; ou permanecerem justapostas e nunca se interceptarem; ou ficarem secretamente escondidas nos interstícios e se deslocarem por capilares e meandros; e, finalmente, se chocarem e se oporem, entrando em conflitos agonísticos ou antagônicos, conforme os interesses contrários e a intensidade das relações de poder. Portanto, no espaço se inscrevem múltiplas escalas e diferentes estratos de tempo. As inscrições espaço-tempo serão acessadas conforme o observador, dependendo, além da concepção de mundo e da imaginação espacial, dos instrumentos conceituais e das ferramentas utilizadas na observação, devendo ser considerado ainda o fato do observador, pelo simples fato de fazer a observação, interferir no objeto. Assim, para tornar inteligível a espacialidade dos fenômenos socioambientais, em função dessa não ser universal mais determinada espaço-temporalmente, o observador precisará identificar a escala que é própria a esses fenômenos e os estratos de tempo que lhes correspondam.

Para Koselleck, o historiador deveria trabalhar "pelo menos implicitamente, com uma teoria de vários estratos do tempo", cada qual se referindo as diferentes experiências cujas trajetórias chegaram até o presente e se expressam nele. Essa proposição, associada à imaginação do

\footnotetext{
${ }^{67}$ Em relação à definição de ator sintagmático, veja a nota 27. Raffestin denomina de ator paradigmático o que "deriva de uma classificação operada com base em critérios que os indivíduos têm em comum", feita por algum ator sintagmático. Portanto é uma repartição da população: territorial (nacionalidade, naturalidade, local de residência etc.); classe (grupo social, renda, escolaridade, etnia, língua, opção política, opção sexual etc.), tipo (eleitor, consumidor, cliente, paciente, idoso, mulher, homem, criança e adolescente, sem teto, diabético, beneficiário etc.). $O$ ator paradigmático, na condição de ator coletivo sem programa, aparece "como um trunfo em relação aos atores sintagmáticos" e são por esses mobilizados, em função das finalidades pretendidas ou nos enfrentamentos das relações de poder. RAFFESTIN, op. cit., p. 41.
} 
espaço com relacionalidade aberta, permitiria questionar a escala-tempo da modernidade, ou seja, a unidimensionalidade do nacional-estatal, inclusive seu caráter eurocêntrico, colonial, heterossexual e branco com devir e sentido da história: civilização, modernização e progresso. É possível relacionar os estratos do tempo, conforme as proposições de Koselleck, ${ }^{68}$ com as diferenças de escala.

Os estratos do tempo têm a ver com os três tempos propostos por Fernand Braudel: a) curta duração refere-se ao tempo evanescente próprio da conjuntura, especialmente da conjuntura política; b) média duração é o tempo da economia, da organização social, do quadro institucional e da vida cultural, que pode ser alguns anos ou décadas, responsável pela produção dos ordenamentos econômicos, sociais e culturais. A longa duração refere-se às estruturas cujo tempo é lento ou muito lento, que parecem imóveis. Entretanto Koselleck apresenta diferenças, pois não se concentra propriamente na duração temporal.$^{69} \mathrm{O}$ primeiro estrato do tempo é a "singularidade" que caracteriza o conjunto de ações que se desenvolvem como sucessão de acontecimentos singulares, referentes a todos os domínios que podem ser tratados historicamente. As reviravoltas singulares podem estabelecer e liberar forças que estavam represadas - "o tempo, ao transcorrer como sucessão de singularidades, também libera inovações que podem ser interpretadas progressivamente". O segundo estrato são as "estruturas de repetição", tais como redes de comunicação e transporte, linguagem, normas jurídicas, entre outros. Essas estruturas garantem e produzem acontecimentos recorrentes, cíclicos e regulares, como se vê no exemplo dado pelo próprio autor: o carteiro que distribui a correspondência diariamente. Isso exige estruturas de repetição que garantam as recorrências, que são precondição da singularidade (entrega da carta escrita por alguém ao destinatário que também é único, no endereço preciso). São estruturas duradouras, de caráter singular, que parecem estáticas, mas que também mudam: surpresa sempre ocorrem; aí aparece o novo.

Koselleck afirma existir um "mínimo temporal" formando um contínuo temporal do antes e depois. Quando esse contínuo se quebra, ocorre o rompimento entre a experiência adquirida e a expectativa do que virá. Todavia, o contínuo precisa e é reconstituído: nasce o novo. Isso motiva os historiadores; querem saber o que ocorreu e como pôde ocorrer. A história

\footnotetext{
${ }^{68}$ KOSELLECK, op. cit., p. 21-25.

${ }^{69}$ Ibidem, p. 24.
} 
sempre se interessou pela singularidade, mudança e o processo que produz o novo: aconteceu por causa disso ou daquilo, mas isso sempre é um depois como não se soube antes. O tempo histórico é delimitado: "a experiência de repetição e o processamento de singularidades sempre se referem a gerações contemporâneas, que se comunicam e trocam experiências".

As singularidades podem ser associadas com a grande escala, porque a aproximação espacial faz sobressair diferenças e realça as especificidades e detalhes singulares; ao contrário da pequena escala que suprime as singularidades, substituídas por agrupamentos homogêneos, à medida que o observador se afasta para abranger áreas cada vez maiores. As estruturas de repetição, por sua vez, podem ser associadas com a média escala, pois é necessário um afastamento mínimo capaz de englobar os limites abrangidos pelas estruturas espaciais e organizacionais que sustentam as recorrências de determinado processo social particular. Os processos sociais que sustentam as estruturas de repetição se localizam territorialmente em áreas delimitadas, cujo centro apresenta maior densidade e na direção das bordas tendem a se esvanecer até cessarem seus efeitos. As estruturas de repetição referem-se a diferentes processos sociais, que podem ser materiais ou simbólicos, tais como redes de transporte, sistemas fabris e sistemas agrícolas; ou, por outro lado, sistemas normativos, religiosos, políticos e de linguagem.

Oterceiro estrato do tempo são as transcendências, que podemos associar com a pequena escala. $O$ tempo das transcendências é muito abrangente e, para ser observado, é preciso um distanciamento considerável, para não se cair na armadilha da falsa singularidade do lugar. As determinantes biológicas, geomorfológicas, climáticas etc., bem como as estruturas culturais e morais, tendem a transcender várias gerações e se estender por extensas áreas. Os processos vinculados a esse estrato de tempo, que Koselleck denomina de "transcendente", são muito lentos e as alterações não podem ser vivenciadas por uma ou mesmo mais gerações. Sobre o terceiro estrato do tempo Koselleck afirma: "Existem tempos históricos que transcendem a experiência de indivíduos e de gerações. ...experiências que já estavam disponíveis antes das gerações contemporâneas e que provavelmente continuarão a atuar depois do desaparecimento delas." Certas concepções de mundo e explicações se reptem em ritmos tão lentos que suas mudanças não podem ser vivenciadas por uma geração. Para Koselleck "Todas as unidades de experiência precisam de um mínimo de transcendência". Os elementos transcendentes podem ser associados à pequena escala porque sua observação demanda eliminar detalhes singulares até se encontrar as homogeneidades 
que formam essas transcendências. Podemos mencionar dois exemplos: a economia do trigo que está no cerne da cultura ocidental; e os arquétipos greco-romanos e judaico-cristãos que estruturam a mentalidade ocidental.

Essa correlação, mesmo que demande mais reflexão e aprofundamento, oferece uma chave para uma abordagem mais crítica da história ambiental, capaz de apontar para outra direção diferente da narrativa descritiva "morfológica", prescritiva (quase sempre de fundo moral) e restritas a estudos regionais. Especificar criticamente a escala, como propõe Racine et. alii., ${ }^{70}$ pode auxiliar na diferenciação dos estratos de tempo que se apresentam e se condensam localmente. Também é ferramenta para que se adote outra concepção de espaço (relacional, aberto e sempre em processo), abrindo-se à multidimensionalidade do vivido territorial. Como se encontra em Boaventura Santos: “A escala é um 'esquecimento coerente' que deve ser levado a cabo coerentemente". ${ }^{71}$ Para Racine et. alii., de onde Boaventura Santos retira a expressão, é necessário que os pesquisadores especifiquem e deixem claro qual a escala que utilizam na pesquisa, pois ocorre sempre que a "escolha das escalas de análise é arbitrária, muitas vezes aleatória, quase sempre não explicitada".

Os fenômenos não são representáveis igualmente em escalas diferentes nem se conservam os mesmos se houver mudança de escala. Determinado fenômeno só é representado em uma dada escala e, ao se mudar a escala, o fenômeno se modifica. Também são diferentes a escala de análise e a escala de ação. No primeiro caso se demanda a pequena escala para se obter a perspectiva adequada para realizar prospecção, diagnóstico e prognóstico; para definir a estratégia e tomar decisões; para elaborar projeto e definir o plano de ação. No segundo caso se demanda a grande escala, pois a passagem do plano para a ação exige aterrissar em um local determinado e deparar-se com variações de situações não previstas ou aleatórias. Em relação à escala de análise é preciso levar em conta os fatores seletivos que respondem a determinadas intencionalidades, mas na escala de ação aparecem a multiplicidade de detalhes e circunstâncias que se sobrepõem e se interpenetram nas práticas, que são sempre territorialmente localizadas.

Racine et. alii. estabelecem uma classificação do que denominam "o gráfico de uma metáfora”. Os atributos da grande escala são: informação factual; dados individuais ou desagregados; fenômenos manifestos; tendência

\footnotetext{
${ }^{70}$ RACINE, RAFFESTIN e RUFFY. op. cit., p. 124.

${ }^{71}$ SANTOS, Boaventura de Souza. op. cit. p. 144.
} 
à heterogeneidade; valorização do vivido e da existência (comunhão). Os atributos da pequena escala são: informação estruturante; dados agregados; fenômenos latentes; tendência à homogeneidade e ao modelo; valorização do organizado e do produtivíssimo (comunicação)..$^{72}$ Boaventura Santos dedicouse a essa questão da escala, buscando aplicá-la à investigação da sociologia jurídica. ${ }^{73} \mathrm{Na}$ investigação de conflitos urbanos por moradia, ele identificou o fenômeno da interlegalidade, ou seja, uma das variáveis presentes nos conflitos era a diferença de escala na qual operavam os atores envolvidos. A implantação de indústria, de infraestrutura ou grande projeto agrícola, por exemplo, realizados por empresa e/ou Estado, são eventos localizados, pois não podem ocorrer se não forem territorializados. Os agentes do grande investimento de capital e os agentes do Estado agem localmente, porém orientados para cumprir as finalidades concebidas na pequena escala (lucro corporativo ou norma jurídica estatal, respectivamente). Por outro lado, os agentes que vivem, elaboram, produzem e agem territorialmente são informados, concebem e julgam orientados pela grande escala, pois o local constitui o seu vivido territorial. Podemos concluir que o choque de escalas não se dá apenas entre categorias do pensamento e escolhas científicas na pesquisa, mas são relações de poder que se manifestam no espaço-tempo, ou seja, num local específico, numa época particular, com uma duração determinada e ritmos próprios.

Os conflitos socioambientais e socioculturais são ocorrências locais que refletem o choque entre atores operando com diferentes escalas. Nos séculos XIX e XX, os grandes investimentos de capital se implantaram em locais específicos com apoio dos Estados nacionais ou coloniais, sem que houvesse considerações de ordem local (ambiental e cultural). Nas últimas décadas do século XX, a crescente opinião pública favorável aos direitos humanos e ambientais forçou os Estados a considerarem outros fatores que não apenas os ganhos econômicos. O Estado, no entanto, faz a mediação dos conflitos surgidos na grande escola com o objetivo de viabilizar os investimentos de capital frente as resistências que emergem em pontos determinados do território nacional. Assim, os grandes investimentos de capitais (mineração, hidroelétrica etc.) atenderiam ao interesse nacional; por outro lado, as "resistências" são vistas como problemas locais a serem resolvidos "localmente". As empresas e o Estado, historicamente, buscaram

\footnotetext{
${ }^{72}$ RACINE, RAFFESTIN e RUFFY. op. cit., p. 129.

${ }^{73}$ SANTOS, Boaventura de Souza. op. cit., p. 144-145.
} 
deslegitimar as contradições por meio do enquadramento unidimensional ao "desenvolvimento do país" e à suposta melhoria para o "povo". ${ }^{74} \mathrm{O}$ importante é reter que o poder, seja o Estado, as corporações ou outra forma de organização, "tende a representar a realidade social e física numa escala escolhida pela sua virtualidade para criar os fenômenos que maximizam as condições de reprodução do poder". ${ }^{75}$

Os conflitos socioambientais e socioculturais foram particularmente agudos no decorrer dos séculos XIX e XX, até o presente, com diversas origens, tais como introdução de grandes investimentos de capital (ferrovias, rodovias, siderurgia, mineração, hidroelétricas etc.); disputa pelo uso e ocupação do solo ou pelo controle dos recursos naturais; ou lutas pelo direito ao espaço urbano ou pelo uso do meio ambiente (um parque, uma lagoa, um rio etc.), entre outros. É na escala pequena que o poder define sua estratégia, porém é na grande escala que ele age e, ao agir, pode corroborar ou contradizer as estruturas e dinâmicas espaço-temporais territorialmente localizadas, isto é, as territorialidades que formam o vivido territorial das populações locais e de seu ambiente. Em relação à primeira é preciso levar em conta fatores seletivos que influenciam as escolhas e as decisões; no segundo caso, os detalhes e circunstâncias se sobrepõem e interpenetram nas práticas, que refletem sempre as multiterritorialidades.

Portanto, as relações de poder passam pela questão da escala, pois essas podem fortalecer ou enfraquecer os lados envolvidos em conflitos socioespaciais e socioambientais, favorecendo ou contrariando as diferentes intenções e interesses dos atores que compõem o jogo relacional. Diferentes posições e atitudes (exploracionista, conservacionista ou preservacionista) refletem diferenças de escala e, como foi dito anteriormente, os fenômenos não são representáveis igualmente em escalas diferentes. A escala afeta diretamente a realidade representada, à medida que a diminuição da escala aumenta a homogeneidade do espaço e vice-versa. A homogeneidade é uma construção analítica não aleatória, que resulta de escolhas sobre o que será agrupado e inserido e o que ficará de fora da representação e será esquecido. Isso exige poder, pois a operação de homogeneizar é feita para tender de-

\footnotetext{
${ }^{74}$ A Usina Hidrelétrica de Belo Monte, que está sendo construída na bacia do rio Xingu, próximo a Altamira, no norte do Pará, na Amazônia, enfrenta forte oposição das comunidades locais e da opinião pública ambientalista. Sobre o assunto o "Blog do Planalto PRESIDÊNCIA DA REPÚBLICA" publicou matéria, em 17 de maio de 2011, com o título: "O Brasil precisa da UHE Belo Monte para crescer e distribuir renda". Disponível em http://blog.planalto.gov.br/o-brasil-precisa-da-uhe-belo-monte-para-crescer-e-distribuir-renda-diz-mme/. Acessado em 1 de setembro de 2015.
}

${ }^{75}$ SANTOS, Boaventura de Souza. op. cit., p. 144-145 
terminada intencionalidade, seja o ator uma empresa, Estado, organização qualquer ou o pesquisador, realizando seu projeto de pesquisa. Todos são atores que operam com escala, conscientemente ou não disso. Em relação ao pesquisador, estar consciente é uma condição crucial: a " questão que se coloca então é saber se, ao passar de uma escala a outra, as modificações na natureza ou na medida da dispersão serão previsíveis." 76

Os objetos do historiador ambiental são socioespaciais não apenas quando estudam as interações entre as várias atividades humanas e o mundo natural ou investigam os fenômenos e recursos naturais que amoldaram padrões de vida humana, mas também quando examinam as mudanças de concepção e atitude em relação à natureza. 0 caráter socioespacial é explícito quando se investiga como as atitudes humanas e suas atividades transformaram a paisagem; ou como as pessoas alteraram o mundo ao seu redor, e quais as consequências dessas alterações para as comunidades naturais e humanas. Essa é uma distinção que se pode atribuir à história ambiental: a natureza socioespacial dos seus objetos, independente se serem abordagens materialistas ou culturalistas. Isso se aplica também aos estudos sobre as percepções humanas e a fixação de significado para o mundo, pois esse processo sempre se refere ao "mundo ao redor", bem como às pesquisas que buscam saber como essas percepções e significados amoldaram a vida cultural e política. Mesmo quando as pesquisas tratam da política ambiental, sejam conservacionistas ou preservacionistas, que fazem parte de acordos internacionais, se está diante de processos socioespaciais.

Portanto, o historiador ambiental não tem como fugir da problemática da escala, porém a questão é saber se as escolhas de escala são conscientemente e a partir de quais referenciais ocorrem. Essas escolhas são necessárias, como explicou Racine et. alii., em função da quantidade enorme e incognoscível dos subconjuntos existente na realidade, sendo que esses crescem exponencialmente quando se amplia a área de observação. Para os autores, "pode-se, pois, definir a escala como uma função do esquecimento coerente que permita uma ação bem sucedida". A escala aparece desde então como um filtro que empobrece a realidade, mas que preserva aquilo que é pertinente em relação a uma dada intenção. ${ }^{77}$ Como todos os dados não interessam à problemática do pesquisador, esse deve selecionar, porém fica a questão sobre quais escolhas estão sendo feitas e o que está sendo esquecido.

\footnotetext{
${ }^{76}$ RACINE, RAFFESTIN e RUFFY. op. cit., p. 125.

${ }^{77}$ Ibidem, p. 128-129.
} 
No nosso ver, a questão da escala deve ser combinada com a problemática relacional e a análise das relações de poder, sem as quais não se chegará a uma história ambiental crítica e coerente.

O ponto de chegada é a constatação de que a imaginação espacial dominante concebe o espaço como dado e fixo, além de localização, ou seja, delimitação de área da ocorrência dos fenômenos a serem investigados, limite e cenário dos acontecimentos. Essa imagem reduz o espaço à noção de superfície (área, zona, campo ou local) e ao que essa contém. Como recomenda Doreen Massey, é preciso mudar a imaginação do espaço, concebendo-o como relacional e aberto, ou seja, trajetórias coetâneas, simultaneidade de diferentes, emergências não previstas e controladas, presença de heterogêneos, acasos, surpresas, incertezas, invisíveis, possibilidades que se abrem ou se fecham, encontros, desencontros e não encontros. Assim, o espaço relacional seria sempre contingente, aberto e nunca pronto, pois se assim não fosse não haveria possibilidade para as transformações, novas emergências e, portanto, para a própria história.

Artigo recebido para publicação em 10/10/2015 Artigo aprovado para publicação em 29/11/2015 